\title{
A case of erosive lichen planus with plantar involvement
} Plantar yerleșimli eroziv liken planus olgusu

Fatma Arzu Kılıç, Sevim Baysak*, Ali Gökhan Eșim, Banu Lebe**

Balıkesir University Faculty of Medicine, Department of Dermatology, Balıkesir, Turkey

*Bandırma State Hospital, Clinic of Dermatology, Balıkesir, Turkey

**Dokuz Eylül University Faculty of Medicine, Department of Pathology, İzmir, Turkey

\begin{abstract}
Lichen planus (LP) affects $0.2-1 \%$ of adult population and the etiology is not fully known. Erosive lichen planus (ELP) is a rare form of LP. LP, characterized by painful erosive plaques involving the oral mucosa and palmoplantar and genital areas, is quite resistant to treatment. Palmoplantar involvement of ELP is very uncommon. Herein, we present an ELP patient with both plantar and dorsal feet involvement in whom the diagnosis of ELP was not established for 7 years. The patient was started on $3 \mathrm{mg} / \mathrm{kg} /$ day cyclosporin-A treatment and regression of the lesions was observed during follow-up. Plantar ELP is a condition which needs years of patient monitoring due to treatment resistance, scar tissue formation, recurrence, association of comorbid pathologies, and malignant transformation potential.
\end{abstract}

Keywords: Erosive lichen planus, palmoplantar, cyclosporin-A

Öz

Liken planus (LP) yetişkin popülasyonda \%0,2-1 oranında görülür ve etiyolojisi tam olarak bilinmemektedir. Eroziv liken planus (ELP), LP'nin nadir gözlenen bir formu olup oral mukoza, palmoplantar bölge ve genital bölgede yerleşen ağrılı erode plaklar ile karakterize bir tablodur ve tedaviye oldukça dirençlidir. ELP'de palmoplantar tutulum oldukça nadir görülür. Bu olgu sunumunda yaklaşık yedi yıldır tanı alamamış, dorsal yüzeylerin de tutulduğu her iki plantar yüze yerleşen bir ELP olgusu sunulmuştur. Hastaya $3 \mathrm{mg} / \mathrm{kg} / \mathrm{gün}$ siklosporin-A tedavisi başlanmış ve takipleri sırasında lezyonların gerilediği saptanmıştır. Plantar ELP tedaviye dirençli olması, skar bırakabilme özelliği, rekürrens gösterebilmesi, komorbid patolojilerle birlikteliği ve prekanseröz özellik göstermesi sebebiyle uzun yıllar takibi gerekli olan bir tablo olması nedeniyle önemlidir. Anahtar Kelimeler: Eroziv liken planus, palmoplantar, siklosporin-A

\section{Introduction}

Lichen planus (LP) is a benign, itchy, chronic inflammatory dermatosis affecting the skin, mucosa, nails and scalp. LP affects $0.2-1 \%$ of adults ${ }^{1}$. Erosive lichen planus (ELP) is a rare form of LP usually involving the oral mucosa and genital area $^{2}$.

Although the etiology of the disease is not fully understood, autoimmune diseases are thought to be associated with LP35. Psychological and emotional disorders are also thought to have a role 4
Palmoplantar involvement, which is characterized by erosive lesions usually accompanied by intense pain, very rarely observed in ELP22. Severe disease may also lead to nail loss 2,6,7. Lesions are also known to be precancerous ${ }^{6}$.

In this report, we present a case of ELP with plantar involvement which responded to cyclosporine-A treatment.

\section{Case Report}

A 65-year-old female patient presented to our clinic with the complaint of painful lesion on her heels for the past 7 years.

Address for Correspondence/Yazışma Adresi: Sevim Baysak MD, Bandırma State Hospital, Clinic of Dermatology, Balıkesir, Turkey Phone: +90 5058177624 E-mail: drsevimharman@hotmail.com Received/Geliş Tarihi: 18.09.2016 Accepted/Kabul Tarihi: 02.01.2017 ORCID ID: orcid.org/0000-0001-9666-5821 
During these 7 years, the patient has received topical treatment and phototherapy in other centers. No biopsy was taken from the patient during these visits.

The patient had a history of cholecystectomy and total abdominal hysterectomy and was taking levothyroxine for Hashimoto's thyroiditis. Physical examination revealed violet purple plaques with erosive areas measuring $4 \times 5 \mathrm{~cm}^{2}$ in size, located at the plantar sides and crossing over to the dorsal side of both feet (Figure 1,2) and reticular plaques on the buccal mucosa.

Histopathological study of the tissue biopsy material taken from the erosive lesions on the plantar side was indicative of LP (Figure

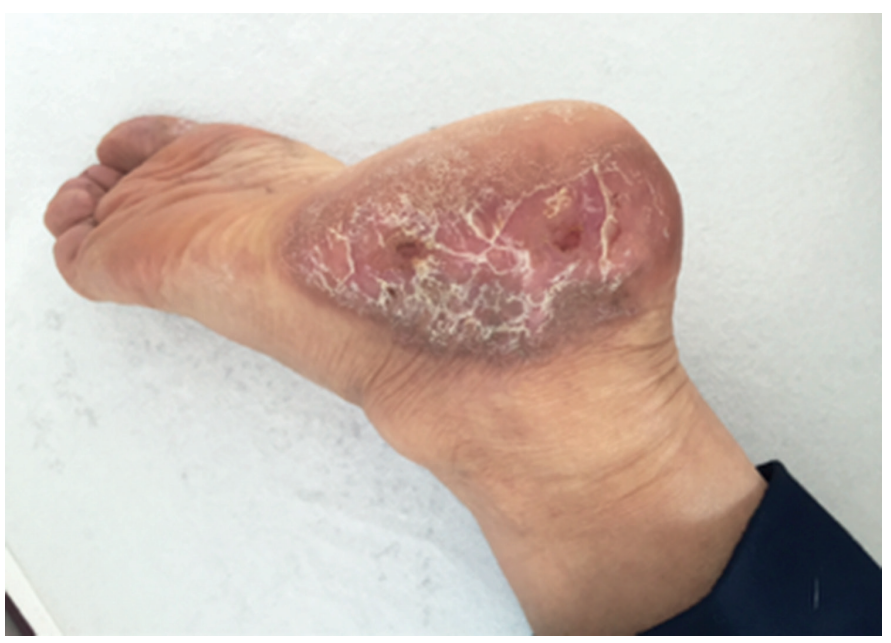

Figure 1. A $5 \times 4 \mathrm{~cm}$ sized plaque lesion located on right plantar area extending dorsal surface of foot was notted before treatment

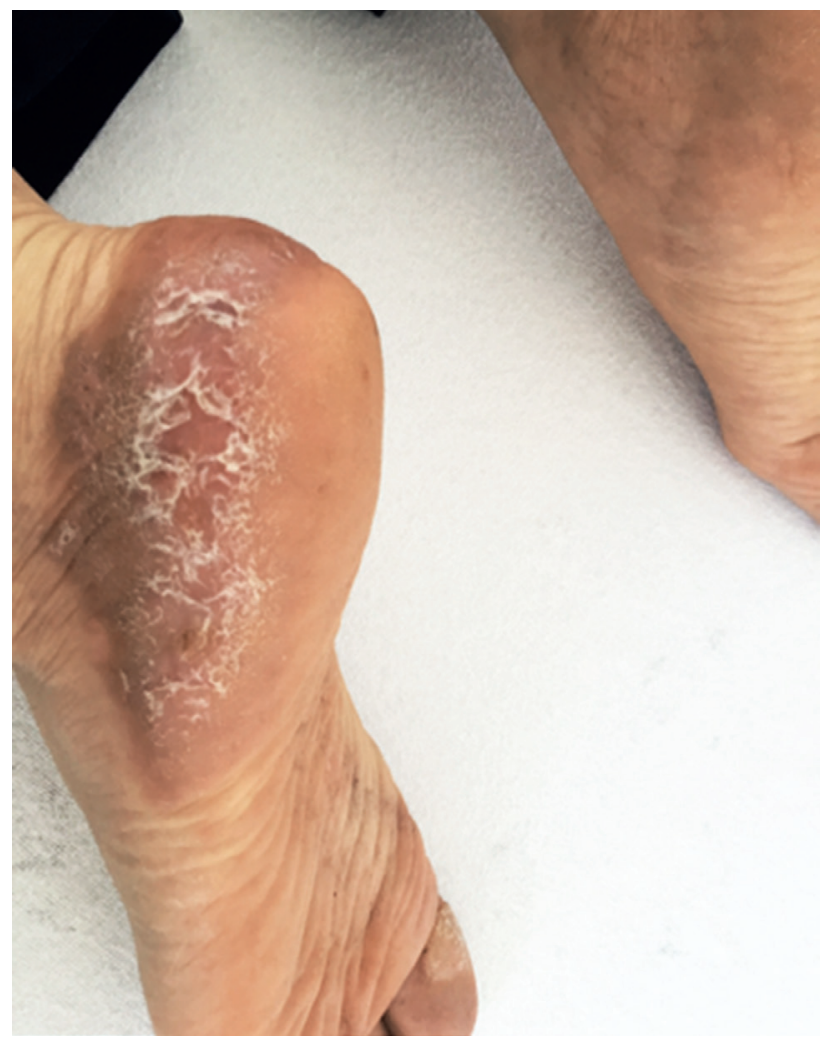

Figure 2. A $5 \times 4 \mathrm{~cm}$ sized plaque lesion located on left plantar area extending dorsal surface of foot was notted before treatment
3). The patient was diagnosed with ELP in the light of clinical and histopathological findings. Laboratory testing showed no pathology other than high anti-thyroglobulin antibody level. Serologic studies for HIV, HBC and HCV were negative.

The patient was started on $3 \mathrm{mg} / \mathrm{kg} /$ day cyclosporine-A treatment. She had monthly follow-ups and gradual dose reduction. On the $5^{\text {th }}$ month of treatment, lesion regression was observed at plantar and dorsal sides of both feet (Figure 4).

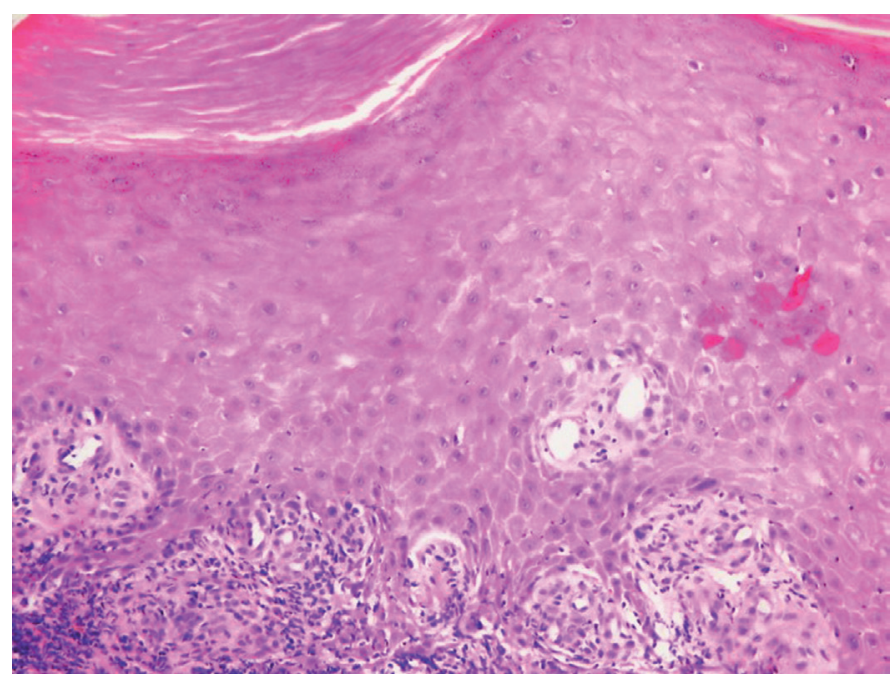

Figure 3. Compact orthokeratosis on the epidermis, thickening of the granular cell layer, irregular acanthosis and basal vacuolar changes, lichenoid lymphohistiocytic cell infiltrates in the dermis, infiltrating dermoepidermal junction (hematoxylin\&eosin, x20 original magnification)

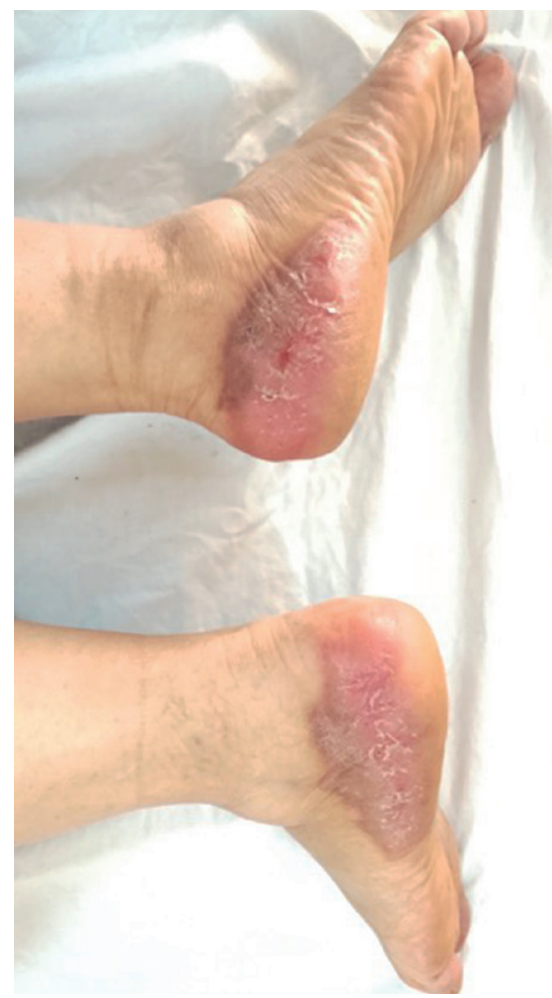

Figure 4. Lesion improved after 5 months duration of $3 \mathrm{mg} / \mathrm{kg} /$ day cyclosporine treatment 


\section{Discussion}

There are more than 20 subtypes of LP according to the location, distribution, shape and morphology of the condition ${ }^{8}$. ELP is a LP subtype affecting mainly the oral and genital mucosa and palmoplantar areas as well as nails 2,9 .

Autoimmune processes are thought to be the cause of ELP3-5 and these reactions are more frequent in women than in men ${ }^{10}$. A study by Akarsu et al. ${ }^{11}$ which evaluated patients with ELP lesions involving the oral mucosa, showed that most of the patients who also had non-mucosal ELP lesions were women. The disease that affects older women more than men may have a correlation with autoimmune reactions occurring more frequently in women. Moreover, high level of stress after menopause in women may contribute to development of the disease.

Plantar involvement in ELP starts with painful, erythematous and bullous lesions on the calcaneus bone $\mathrm{e}^{2,12}$ that were also present in our case. Lesions have a tendency to spread to the plantar side and the nails ${ }^{2,9,12}$. Koebner phenomenon is known to be positive in LP and lesions may take 2 years to develop after trauma ${ }^{13}$. Pain, the duration of the disease and spread of the lesions that first appeared on the heel may be the result of constant exposure to trauma due to lesion location in this case.

While the etiology of the disease is not fully understood, studies show damage to keratinocytes following an immune reaction caused by CD8+ lymphocytes where production of multiple mediators (interleukin-12, interferon- $\gamma$, tumor necrosis factor- $\alpha$, RANTES, MMP-9 and transforming growth factor- $\beta 1$ ) gets suppressed and T-cell mediated immunity gets irregular ${ }^{3-5}$.

In cases of LP with palmoplantar involvement, presence of a hypertrophic morphology is determined. Beside the typical findings of $L P$, thinning of all epidermal layers, pigmentary incontinence in the dermis, and melanophages may be seen ${ }^{8}$. The histopathological findings of the present case were compatible with the literature and the presence of lymphohistiocytic cell infiltration may support the underlying autoimmune reaction.

ELP is documented to be associated with primary biliary cirrhosis, autoimmune thyroiditis, Sjögren syndrome and diabetes mellitus ${ }^{6}$. Cases of ELP associated with hepatitis have been reported, however, the underlying mechanism of this association has not been revealed ${ }^{14}$. There were associated diseases in the present case. The patient had comorbidities which are open to discussion as to whether they were a result of age or the underlying mechanism of autoimmune reactions in ELP. Comorbid pathologies (especially hypothyroidism) may be a part of this process in this case

In the literature, there are many agents used in the treatment but evidence-based results are insufficient. ELP with its history of resistance to systemic and topical treatment, have been subject to multiple treatment options, but effective treatment has not been achieved ${ }^{2,6,7}$. In view of the role of T-cells, cyclosporine, calcineurin inhibitors such as tacrolimus and pimecrolimus treatments which suppress the T-cell activity are used in the treatment of ELP ${ }^{15}$. Treatment protocols allowing topical/systemic steroids, topical/systemic retinoids, topical cyclosporine, topical triamcinolone acetonide and psoralen + ultraviolet A baths to be used in conjunction with each other have been created $^{6,16}$. These treatments helped lesion regression but relapses were observed. One example is tacrolimus $0.1 \%$ used with ultraviolet A helping regression, but no prevention against relapse ${ }^{6}$.

In some studies, corticosteroids, dapsone, etretinate, cyclosporine, mycophenolate mofetil, platelet-derived growth factor, griseofulvin and thalidomide were used and low-dose, low-molecular-weight heparin was added to these treatments and in 4-13 weeks, successful treatment responses were achieved ${ }^{17-19}$. Conrotto et al. ${ }^{20}$ reported that clobetasol propionate was more effective and more low-priced treatment than cyclosporine, in their study comparing these two treatment choices in patients with oral LP. On the other hand, the same study revealed that cyclosporine had longer effect and fewer side effects than clobetasol20. Another study comparing topical cyclosporine and triamcinolone revealed no precedence ${ }^{21}$.

In the present case, $3 \mathrm{mg} / \mathrm{kg} /$ day cyclosporine-A treatment was started. Cyclosporine dose was gradually reduced and stopped. Monthly follow-ups revealed regression and improvement in quality of life but it is obvious that without long-term follow-up, it would be wrong to comment about relapse of the disease. Additionally whether topical treatment and phototherapy the patient had before she presented to our clinic were started upon diagnosis or not and also response to treatment was not known. Current lesions may also be a relapse of the disease after the initial treatment.

Consequently, ELP is an uncommon chronic disorder with recurrences. Resistance to many treatment options, recurrences, comorbid pathologies and malignancy potential requiring long-term monitoring of all patients are the matters to consider when dealing with ELP.

\section{Ethics}

Informed Consent: Consent form was filled out by all participants. Peer-review: Externally peer-reviewed.

\section{Authorship Contributions}

Surgical and Medical Practices: F.A.K., A.G.E., Concept: F.A.K., S.B., Design: F.A.K., S.B., A.G.E., Data Collection or Processing: F.A.K., S.B., Analysis or Interpretation: F.A.K., S.B., B.L., Literature Search: S.B., Writing: F.A.K., S.B.

Conflict of Interest: No conflict of interest was declared by the authors.

Financial Disclosure: The authors declared that this study received no financial support.

\section{References}

1. Atzmony L, Reiter O, Hodak E, Gdalevich M, Mimouni D: Treatments for Cutaneous Lichen Planus: A Systematic Review and Meta-Analysis. Am J Clin Dermatol 2016;17:11-22.

2. Romero W, Giesen L, Navajas-Galimany L, Gonzalez S: Erosive lichen planus: a therapeutic challenge. An Bras Dermatol 2016;91:84-6.

3. Amirchaghmaghi M, Pakfetrat A, Delavarian Z, Ghalavani H, Ghazi A: Evaluation of the Efficacy of Curcumin in the Treatment of Oral Lichen Planus: A Randomized Controlled Trial. J Clin Diagn Res 2016;10:ZC134-7.

4. Lu R, Zeng X, Han Q, Lin M, Long L, Dan $H$, et al: Overexpression and selectively regulatory roles of $\mathrm{IL}-23 / \mathrm{IL}-17$ axis in the lesions of oral lichen planus. Mediators Inflamm 2014;2014:701094

5. Roopashree M, Gondhalekar RV, Shashikanth M, George J, Thippeswamy S, Shukla A: Pathogenesis of oral lichen planus-a review. J Oral Pathol Med 2010;39:729-34.

6. Avilés-Izquierdo J, Blanco VP, Roldan FA: Erosive Palmoplantar Lichen Planus. Acta Dermosifiliogr 2012;103:448-50. 
7. Elewa R, Altenburg A, Zouboulis C: Recalcitrant severe erosive cutaneous lichen planus treated with extracorporeal photopheresis monotherapy. $\mathrm{Br} J$ Dermatol 2011;165:441-3.

8. Ceyhan AM, Başak PY, Akkaya VB, Erturan I, Ciriş M: Liken planusun farklı klinik yüzleri: olgu sunumu. SDÜ Tıp Fakültesi Dergisi 2007;14:33-6.

9. Garcia Perez A, Rodriguez Pichardo A, Bueno Montes J: Erosive plantar lichen planus with onycho-atrophy. Med Cutan Ibero Lat Am 1982;10:89-92.

10. Duman $\mathrm{HE}$, Köse $\mathrm{AA}$, İşsever $\mathrm{H}$ : Alopesi areatalı olgularda ve yakınlarında kötü prognostik faktörlerin incelenmesi. Turkderm 2015;49:9-13.

11. Akarsu S, Özkan AŞ, Gündüz I, Ünal F, Yaşar E, Poyraz K: Liken planuslu olgularda mukoza tutulum sıklığı. DEÜ Tıp Fakültesi Dergisi 2007;21:155-8.

12. Jimenez-Sanchez M, Ferrandiz L, Moreno-Ramirez D, Vallejo-Benítez A, Camacho-Martinez F: Erosive palmoplantar lichen planus. Actas Dermosifiliogr 2012;103:448-50.

13. Rifaioğlu EN, Şen BB, Ekiz Ö: Tatuaj Komplikasyonu Olarak Koebner Fenomeni; Psoriasis Tanılı Bir Olgu. Türk Dermatoloji Dergisi 2014;1:244-5.

14. Günaştı S, Tuncer I, Hasbay B, Denli Y, Uzun S: Liken planus pemfigoidesin klinik, histolojik ve immünoflöresan özellikleri: iki olgu sunumu. Turk J Dermatol 2010;4:25-8.
15. Bayramgürler D, Demirsoy EO: Zorlu Oral Hastaliklarda Güncel Tedavi: Oral Liken Planus, Oral Lökoplaki/Current Treatment Options in Challenging Oral Diseases: Oral Lichen Planus, Oral Leukoplakia. Turkderm 2012;46:110.

16. Ojeda T, Rodríguez-Rey E, Camacho F: Ulcerative lichen planus of the sole treated with tacrolimus, 0.1\%. Actas Dermosifiliogr 2011;102:383-4.

17. Neville JA, Hancox JG, Williford PM, Yosipovitch G: Treatment of severe cutaneous ulcerative lichen planus with low molecular weight heparin in a patient with hepatitis C. Cutis 2007;79:37-40.

18. Stefanidou M, loannidou D, Panayiotides J, Tosca A: Low molecular weight heparin; a novel alternative therapeutic approach for lichen planus. $\mathrm{Br} J$ Dermatol 1999;141:1040-5.

19. Navarrete-Franco G, Ramos-Garibay A, Gonzalez-Gonzalez M, Franco-Guzman AM: Liquen plano erosivo plantar. Dermatol Rev Mex 2015;59:317-20.

20. Conrotto D, Carbone M, Carrozzo M, et al: Ciclosporin vs. clobetasol in the topical management of atrophic and erosive oral lichen planus: a double blind, randomized controlled trial. Br J Dermatol 2006;154:139-45.

21. Lopez-Jornet P, Camacho-Alonso F, Salazar-Sanchez N: Topical tacrolimus and pimecrolimus in the treatment of oral lichen planus: an update. J Oral Pathol Med 2010;39:201-5. 